\title{
Peran Dukungan Suami bagi Kesejahteraan Psikologis Jurnalis Perempuan
}

\section{The Role of Husband Support for Psychological Well-being of Female Journalist}

\author{
Riani Putriyani ${ }^{1}$, Ratih Arruum Listiyandini ${ }^{2}$ \\ ${ }^{1,2}$ Fakultas Psikologi Universitas YARSI, Jakarta, Indonesia \\ rianiputriyani@gmail.com
}

KATA KUNCI Dukungan Sosial, Jurnalis, Kesejahteraan Psikologis,
Perempuan, Suami

KEYWORDS Social Support, Psychological Well-Being, Female, Journalist, Husband

ABSTRAK Perempuan menikah yang bekerja, terutama mereka dengan profesi sebagai jurnalis memiliki tantangan tersendiri untuk mencapai kesejahteraan psikologis yang optimal. Tujuan dari penelitian ini adalah ingin mengetahui peran dukungan suami terhadap kesejahteraan psikologis jurnalis perempuan. Penelitian menggunakan pendekatan kuantitatif dan desain cross-sectional. Melalui teknik pengambilan sampel snowball sampling, penelitian dilakukan pada 100 orang jurnalis perempuan dengan menggunakan adaptasi skala Psychological WellBeing Scale (SPWB) dan kuesioner dukungan suami yang disusun sendiri oleh peneliti. Berdasarkan hasil uji regresi, dukungan suami ditemukan berpengaruh positif dan signifikan bagi kesejahteraan psikologis jurnalis perempuan, khususnya pada dimensi penguasaan lingkungan dan tujuan hidup. Dengan demikian, menjadi penting bagi suami untuk bisa memberikan dukungan kepada pasangannya dalam rangka membantu peningkatan kesejahteraan psikologis para jurnalis perempuan.

ABSTRACT Married woman who are working as journalist have their own challenge to achieve optimal psychological well-being. This research aims to investigate how is the role of husband's social support towards psychological well-being of female journalists. The study used quantitative approach and cross-sectional design. By snowball sampling method, research was conducted to 100 female journalist using adapted scale of psychological well-being (SPWB) and social support questionnaire constructed by the researcher. Based on regression analysis, social support from husband positively and significantly influence psychological well-being of female journalists, with mostly contributes to environmental mastery dimension and life purpose. Thus, it is imperative for female journalist husband to give support for their spouse in order to enhance the psychological well-being of female journalists. 


\section{PENDAHULUAN}

Peran perempuan identik dengan mengurus anak, suami, dan rumah tangga. Namun saat ini peran perempuan telah bergeser. Hal ini terlihat dari meningkatnya jumlah perempuan yang bekerja. Berdasar hasil survei yang dilakukan perusahaan konsultan manajemen, layanan teknologi, serta outsourcing, sebanyak $42 \%$ perempuan di Indonesia memilih bekerja dibandingkan harus tinggal diam di rumah, meskipun tidak memiliki masalah keuangan (Deny, 2014). Berdasarkan hasil Survei Angkatan Kerja Nasional (Sakernas) yang dilakukan oleh Badan Pusat Statistik (BPS) setiap tahun, secara nasional terlihat pada tahun 2011, jumlah pekerja perempuan sebesar 48,43\%. Portal Resmi Provinsi DKI Jakarta (2014) juga menyatakan pekerja di kalangan perempuan meningkat pada tahun 2014 dari 1.742,62 menjadi $1.759,74$.

Peningkatan perempuan yang bekerja diduga karena dorongan ekonomi, yaitu tuntutan keluarga untuk menambah penghasilan, serta semakin terbukanya kesempatan perempuan untuk bekerja (Badan Pusat Statistik, 2008). Peningkatan pendidikan menjadi salah satu faktor perempuan untuk bekerja. Keputusan seorang perempuan untuk bekerja pun tentunya diikuti oleh manfaat-manfaat bagi dirinya sendiri, suami dan anak-anaknya. Nieva dan Gutek (1981) menuliskan beberapa efek kumulatif dari perempuan yang bekerja menurut beberapa ahli. Sebagai contoh, bekerja dapat meningkatkan perasaan kompeten dan wellbeing. Meningkatnya perasaan kompeten melalui bekerja disebabkan oleh gaji yang diterima yang dapat menimbulkan rasa ketidaktergantungan secara finansial kepada suami atau orang lain. Rasa ketidaktergantungan pada segi finansial ini

juga memungkinkan perempuan untuk dapat membantu urusan rumah tangga dan kebutuhan tambahan anak.

Di antara beberapa jenis pekerjaan yang diminati perempuan adalah sebagai jurnalis. Namun berdasarkan data Direktori Dewan Pers tahun 2006, jumlah wartawan tetap di DKI Jakarta lebih banyak laki-laki dibandingkan perempuan. Jumlah wartawan laki-laki sebanyak 3.192 orang dan wartawan perempuan sebanyak 558 orang (Dennis, 2008). Hanya sekitar 18,6\% jurnalis perempuan dari total 1868 anggota AJI (Asosiasi Jurnalis Indonesia) seIndonesia. Kurangnya jurnalis perempuan, seringkali bukan karena ketidakmampuan perempuan dalam melaksanakan tugas jurnalistik, namun disebabkan pekerjaan ini memang sudah dilabelkan pada laki-laki. Banyak faktor yang menggambarkan dunia media massa didominasi dengan laki-laki. Sementara jurnalis perempuan masih sering dipandang sebelah mata, karena perempuan dianggap tidak bisa disamakan dengan lakilaki dalam hal pekerjaan dibidang jurnalistik (Lampe, 2014).

Perempuan yang bekerja sebagai jurnalis memiliki tanggung jawab besar. Berbagai tugas yang harus diselesaikan, misalnya turun ke daerah konflik, banyaknya deadline yang harus diselesaikan, serta tidak ada batasan waktu sehingga harus meninggalkan keluarga (Suhardjo, 2012). Seperti halnya yang disampaikan oleh jurnalis perempuan bahwa:

“...institut tempat bekerja saya tidak
membedakan antara laki-laki atau
perempuan dalam memberlakukan
penugasan maupun promosi.
Misalnya harus meliput beberapa ke
daerah konflik yang seharusnya tugas
laki-laki dan harus membagi peran
antara pekerjaan dan bagaimana
posisi saya dalam keluarga (istri)...”

Dengan banyaknya tuntutan dan peran yang harus dialami, maka jurnalis perempuan rentan mengalami masalah terkait kesejahteraan psikologis. Kesejahteraan psikologis merupakan realisasi dan pencapaian penuh dari potensi individu di mana individu dapat menerima segala kekurangan dan kelebihan dirinya, mandiri, mampu membina hubungan yang positif dengan orang lain, dapat menguasai lingkungannya dalam arti mampu 
memodifikasi lingkungan agar sesuai dengan keinginannya, memiliki tujuan dalam hidup, serta terus mengembangkan pribadinya (Ryff, 1989).

Terkait kesejahteraan psikologis, ditemukan bahwa perempuan bekerja seringkali memiliki masalah dalam kesejahteraan psikologis. Beberapa penelitian menunjukkan terdapat beberapa tantangan psikologis yang dialami jurnalis perempuan yang sudah menikah. Di antaranya merasa kelelahan, terbebani, dan penuh dengan risiko (Febriarni, 2012). Pada penelitian Lampe (2014), kebanyakan menganggap bahwa perempuan kadangkala tidak mampu mengikuti kerja wartawan yang tidak mengenal waktu sementara pekerjaan domestik di rumah juga tetap menjadi prioritas utama. Kondisi ini mengindikasikan adanya kesulitan di dalam dimensi penguasaan lingkungan. Hal tersebut serupa dengan yang diungkapkan salah satu jurnalis perempuan menyatakan bahwa:

“...permasalahan yang paling banyak
terjadi pada jurnalis perempuan
terkait waktu, beban tenaga,
pengurusan anak, dan banyak
perempuan yang masih menginginkan
bekerja sebagai jurnalis, tetapi harus
resign karena sudah berkeluarga.."

Kesejahteraan psikologis dapat dipengaruhi oleh beberapa faktor, salah satunya adalah dukungan sosial (Wells, 2010). Dukungan sosial menurut Gottlieb dan Bergen (2010) merupakan informasi verbal atau nonverbal, saran, bantuan yang nyata, atau tingkah laku yang diberikan oleh orang-orang yang akrab dengan subjek di dalam lingkungan sosialnya, seperti berupa kehadiran dan hal-hal yang dapat memberikan keuntungan emosional atau berpengaruh pada tingkah laku penerimanya.

Pada jurnalis perempuan yang sudah menikah, ditemukan bahwa dukungan sosial dari suami merupakan faktor yang penting. Hal tersebut sejalan dengan hasil wawancara dengan seorang jurnalis perempuan di salah satu jurnalis perempuan televisi swasta menemukan bahwa:

“...walaupun suami saya tidak pernah
megutarakan secara tegas selalu
mendukung pekerjaan saya, dia selalu
membuktikannya dengan selalu
menghandle pekerjaan rumah yang
seharusnya saya
mengerjakan..." yang

Dengan adanya dukungan sosial emosional berupa perhatian dan kasih saying, jurnalis perempuan akan lebih tenang dalam melakukan aktivitasnya.

Pada penelitian ini, peneliti melakukan pengembangan dari penelitian sebelumnya. Penelitian yang terkait dengan jurnalis perempuan masih sedikit dilakukan apalagi yang terkait dengan variabel dukungan sosial dan kesejahteraan psikologis. Penelitian sebelumnya yang dilakukan oleh Sulaeman (2016) dan Lahagu (2012) lebih berfokus mengenai diskriminasi jurnalis perempuan serta meragukan kemampuan perempuan di bidang jurnalistik. Namun, penelitian tersebut tidak melihat secara khusus aspek kesejahteraan psikologis pada jurnalis perempuan. Oleh karena itu, peneliti tertarik mengetahui seberapa besar peran dukungan suami terhadap kesejahteraan psikologis pada jurnalis perempuan yang sudah menikah.

Penelitian yang dilakukan ini dirancang dengan pendekan penelitian kuantitatif dan desain cross-sectional serta bersifat eksplanatori. Dalam hal ini, terdapat variabel bebas, yaitu adalah dukungan suami dan variabel terikatnya adalah dimensi-dimensi dari kesejahteraan psikologis. Peneliti memiliki hipotesis bahwa dukungan suami akan berpengaruh signifikan terhadap setiap dimensi kesejahteraan psikologis pada jurnalis perempuan.

\section{Kesejahteraan psikologis}

Kesejahteraan psikologis memiliki definisi yang subjektif, namun dari hasil penelitian yang telah dilakukan pada 
berbagai negara, seseorang dapat dikatakan memiliki kesejahteraan psikologis yang baik apabila memiliki pemikiran positif baik terhadap dirinya sendiri maupun orang lain, dapat mengambil keputusan, dapat mengatur hidupnya, memiliki tujuan hidup, dapat mengembangkan diri, serta mampu mengatasi dan beradaptasi dengan lingkungan (Wells, 2010).

Dimensi kesejahteraan psikologis yang dirumuskan oleh Ryff bersifat multidimensional. Ryff sendiri membagi kesejahteraan psikologis ke dalam 6 dimensi (Ryff \& Singer, 1996). Menurut Ryff dan Singer (1996), individu yang memiliki kesejahteraan psikologis yang baik merupakan individu yang dapat menerima keadaan dirinya serta merasakan hal-hal positif pada diri dan lingkungannya, mampu melihat potensi dan mengembangkannya, dan dapat berfungsi dengan sebaik-baiknya terhadap lingkungan.

Dimensi yang pertama adalah penerimaan diri. Dimensi penerimaan diri merupakan aspek penting dalam kesejahteraan seseorang. Penerimaan diri dalam hal ini bukan berarti rasa percaya diri yang berlebihan pada seseorang, tetapi kesadaran seorang individu untuk menyadari serta menghargai kekurangan yang ada pada dirinya yang nantinya individu tersebut berusaha mengatasi kekurangannya, mengakui dan menerima diri sendiri baik positif maupun negatif serta dapat menerima dan melihat masa lalunya sebagai hal yang positif.

Kedua adalah hubungan positif dengan orang lain. Dalam kesejahteraan psikologis menekankan pentingnya memiliki hubungan positif dengan orang lain dan hal tersebut dapat terlihat dari cara berinteraksi dengan orang lain. Individu yang memiliki hubungan positif dengan orang lain merasakan kesenangan ketika berinteraksi dengan orang lain, merasakan empati, memiliki kehangatan, kepercayaan, dan hubungan dekat dengan orang lain.

Selanjutnya adalah otonomi. Dimensi ini mengacu pada kemandirian seseorang dalam menjalani kehidupannya. Individu yang mampu menguasai dirinya sendiri, mengatasi tekanan sosial, mampu bertindak dan mengambil keputusan atas apa yang menjadi pemikiran dan pendapatnya sendiri.

Faktor terpenting lainnya dari kesejahteraan psikologis adalah kemampuan seseorang untuk menguasai dan mengendalikan diri dengan lingkungan sekitar dengan kemampuan beradaptasi, mengembangkan potensi dalam berbagai situasi dan kondisi di lingkungan. Memiliki keterampilan dalam menggunakan kesempatan dan peluang yang muncul.

Kemampuan seseorang untuk menemukan makna dan arah dari pengalamannya untuk menetapkan tujuan dalam hidupnya. Individu yang memiliki tujuan hidup, merasa masa lalu dan masa sekarang yang sedang dijalani memiliki arti, serta memiliki keyakinan bahwa mereka memiliki tujuan hidup dan kehidupan yang mereka jalani bukan merupakan suatu hal yang sia-sia menunjukkan nilai yang tinggi pada dimensi tujuan hidup.

Terakhir, dimensi penerimaan diri. Dimensi ini berkaitan dengan kemampuan seseorang untuk menyadari potensi dan bakatnya serta kemampuan untuk mengembangkan hal-hal baru. Hal tersebut diasosiasikan dengan sikap keterbukaan seeorang terhadap pengalaman dan hal baru.

Beberapa faktor yang ditemukan berhubungan dengan kesejahteraan psikologis diantaranya adalah faktor demografis (usia, status pernikahan, gender, sosial ekonomi) (Wells, 2010), faktor hubungan sosial dan dukungan sosial (Wells, 2010), dan beberapa faktor lainnya, seperti pengalaman hidup (Ryff, 1989), locus of control (Ryff, dalam Wells, 2010), dan religiusitas (Krause \& Ellison, 2003).

\section{Dukungan sosial}

Menurut Johnson dan Jhonson (1991), dukungan sosial merupakan keberadaan orang lain yang dapat 
diandalkan untuk memberi bantuan, semangat, penerimaan dan perhatian sehingga bisa meningkatkan kesejahteraan hidup bagi individu yang bersangkutan. Menurut Baron dan Byrne (2005), dukungan sosial adalah kenyamanan secara fisik dan psikologis yang diberikan oleh orang lain. Ditambahkan oleh Sarafino (2011), kebutuhan, kemampuan, dan sumber dukungan sosial mengalami perubahan sepanjang kehidupan seseorang dan keluarga merupakan lingkungan pertama yang dikenal oleh individu dalam proses sosialisasi. Berdasarkan definisi mengenai dukungan sosial, maka dukungan suami dapat diartikan sebagai bantuan yang diberikan oleh suami sehingga mampu membuat pasangan merasa nyaman baik secara fisik maupun psikis sebagai bukti bahwa pasangan diperhatikan dan dicintai (Nurmadina, 2008).

Sarafino (2011) membagi dukungan sosial ke dalam empat komponen, yang terdiri dari: dukungan emosional (emotional support), dukungan penghargaan (esteem support), dukungan instrumental (tangible or instrumental support), dan dukungan informasi (informational support). Dukungan emosional merupakan bentuk dukungan yang melibatkan adanya ekspresi rasa empati dan kepedulian terhadap individu, misalnya seorang suami yang mau mendengarkan keluhan istrinya mengenai pekerjaannya. Selanjutnya, dukungan penghargaan, yaitu melibatkan adanya usaha untuk memberikan kepercayaan diri dan harga diri pada orang yang diberikan dukungan. Contoh dari bentuk dukungan penghargaan adalah suami yang memberikan pujian dan apresiasi atas pretasi istrinya di tempat kerja. Bentuk dukungan berikutnya adalah dukungan instrumental, bentuk dukungan berupa pemberian bantuan langsung, seperti bantuan materi atau tindakan membantu lainnya. Dalam hal ini misalnya, suami bersedia mengantarkan istrinya ke tempat bekerja. Terakhir adalah dukungan informasional, yaitu bentuk dukungan berupa pemberian nasehat, pengarahan, saran, atau umpan balik tentang bagaimana cara menyelesaikan permasalahan. Contoh dari bentuk dukungan ini misalnya pada saat suami memberikan masukan mengenai masalah-masalah yang terjadi di tempat kerja istri. Keempat bentuk dukungan sosial ini diasumsikan tidak terpisahkan, saling berkaitan erat satu sama lain, dan semakin banyak bentuk dukungan yang muncul, maka semakin kuat dukungan sosial secara keseluruhan.

Menurut Sarafino (2011), faktor yang mempengaruhi dukungan sosial di antaranya adalah penerima dukungan yang harus mau menerima bantuan dari orang lain, penyedia dukungan harus memiliki sumber untuk memberikan dukungan, serta komposisi atau struktur jaringan sosial.

\section{METODE PENELITIAN Partisipan Penelitan}

Teknik pengambilan sampel dalam penelitian ini adalah nonprobability sampling. Adapun teknik pengambilan sampel dengan menggunakan teknik "Snowball Sampling". Azwar (2012) mengatakan bahwa ukuran sampel tidak ada angka yang dapat dikatakan pasti, namun jumlah sampel yang melebihi 60 orang dapat dikatakan cukup banyak. Pada penelitian ini peneliti mengambil sampel sebanyak 100 orang. Adapun kriteria sampel pada penelitian ini, yaitu:

1. Jurnalis perempuan yang sudah menikah dan tinggal bersama suami

2. Usia 20-40 tahun (dewasa muda)

3. Usia penikahan minimal 1 tahun

4. Periode bekerja minimal 1 tahun

5. Mempunyai anak maupun tidak mempunyai anak

Dari 100 orang jurnalis perempuan yang menjadi partisipan dalam penelitian ini, ditemukan bahwa sebagian besar usia responden berada pada rentang usia 23-28 tahun (58\%), sisanya adalah 29-34 tahun (33\%), dam 35-40 (9\%). Usia pernikahan sebagian besar pada rentang kurang dari 2 tahun $(65 \%)$, dan yang sudah menikah lebih dari 2 tahun sebesar 35\%. Sebagian besar 
partisipan $(54 \%)$ sudah memiliki anak, dan sisanya $46 \%$ belum memiliki anak.

Terkait dengan status pekerjaan, ditemukan bahwa sebagian besar memiliki status kontrak (58\%), dan yang berstatus karyawan tetap adalah $42 \%$. Selain itu, sebagian besar partisipan sudah bekerja lebih dari 3 tahun (63\%) dan yang kurang dari 3 tahun adalah 37\%. Menurut mereka, sumber dukungan sosial utama mereka pada saat bekerja adalah suami $(73 \%)$ dan sisanya $27 \%$ adalah orangtua, teman, dan pihak lainnya.

\section{Instrumen Penelitian}

\section{Skala Dukungan suami}

Skala dukungan suami dibuat oleh peneliti. Skala ini disusun berdasarkan 4 komponen dukungan sosial dari Sarafino (2011), yaitu dukungan emosional, dukungan penghargaan, dukungan instrumental, dan dukungan informasi. Skala dukungan suami ini bersifat unidimensi karena setiap domain diasumsikan berkaitan erat satu dengan lainnya. Skala terdiri dari 29 item, dengan koefisien reliabilitas keseluruhan $\alpha=0.937$ dan rentang korelasi item-total adalah $\mathrm{r}=$ 0.345-0.678.

\section{Skala Kesejahteraan psikologis}

Skala kesejahteraan psikologis yang digunakan pada penelitian ini adalah skala kesejahteraan psikologis (SPWB) oleh Ryff yang juga pernah diadaptasi sebelumnya oleh Brebahama \& Listiyandini (2016). Skala ini merupakan skala multidimensional yang terdiri dari 6 subskala yaitu skala penerimaan diri, hubungan positif dengan orang lain, otonomi, penguasaan lingkungan, tuajuan hidup, dan pertumbuhan pribadi. Pada skala ini diwakili item yang valid pada setiap dimensi, yaitu penerimaan diri (7 item), hubungan positif dengan orang lain (5 item), otonomi (7 item), penguasaan lingkungan (4 item), tujuan hidup (4 item), dan pertumbuhan pribadi ( 7 item). Koefisien reliabilitas pada setiap dimensi berkisar antara $\alpha=0.665-0.827$, dengan korelasi item-total sebesar $r>0.2$, sehingga tergolong memadai.

\section{Uji Statistik}

Pada penelitian ini, peneliti melakukan teknik analisis data uji regresi sederhana. Uji regresi sederhana dilakukan dengan menjadi dukungan suami sebagai IV, dan tiap dimensi dari kesejahteraan psikologis sebagai DV. Sebelum melakukan uji regresi sederhana, peneliti juga akan melakukan uji normalitas dan linearitas sebagai syarat dasar uji asumsi klasik.

\section{ANALISIS \&HASIL}

\section{Gambaran Kesejahteraan Psikologis Jurnalis Perempuan}

Berdasarkan hasil perhitungan rerata pada setiap dimensi kesejahteraan psikologis, ditemukan gambaran profil kesejahteraan psikologis partisipan sebagai berikut:

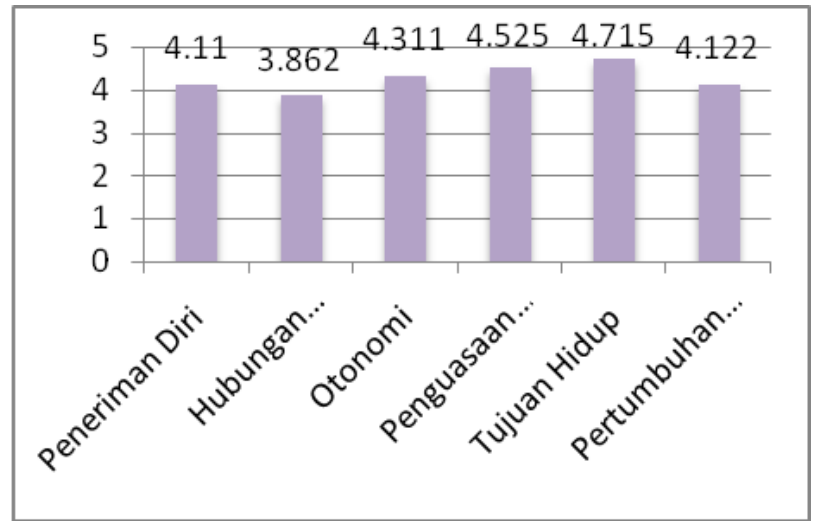

Grafik 1. Profil Kesejahteraan Psikologis

Berdasarkan grafik 1, berdasarkan skala 17, ditemukan bahwa dimensi kesejahteraan psikologis yang ditemukan paling tinggi adalah pada tujuan hidup $(M=4.715)$ dan paling rendah pada dimensi hubungan positif dengan orang lain ( $M=3.86)$.

\section{Hasil Uji Normalitas dan Linearitas}

Sebelum melakukan uji regresi, peneliti melakukan uji normalitas dan linearitas. Berdasarkan hasil penghitungan, pada penelitian ini data terdistribusi normal 
dan hubungan antar variabel memenuhi syarat linearitas $(\mathrm{p}>0.05)$.

\section{Hasil Uji Regresi Sederhana: Pengaruh Dukungan Suami terhadap Kesejahteraan Psikologis Jurnalis}

Berikut adalah hasil uji regresi sederhana yang menggambarkan pengaruh dari dukungan suami terhadap kesejahteraan psikologis pada jurnalis perempuan:

\section{Tabel 1. Hasil Uji Regresi}

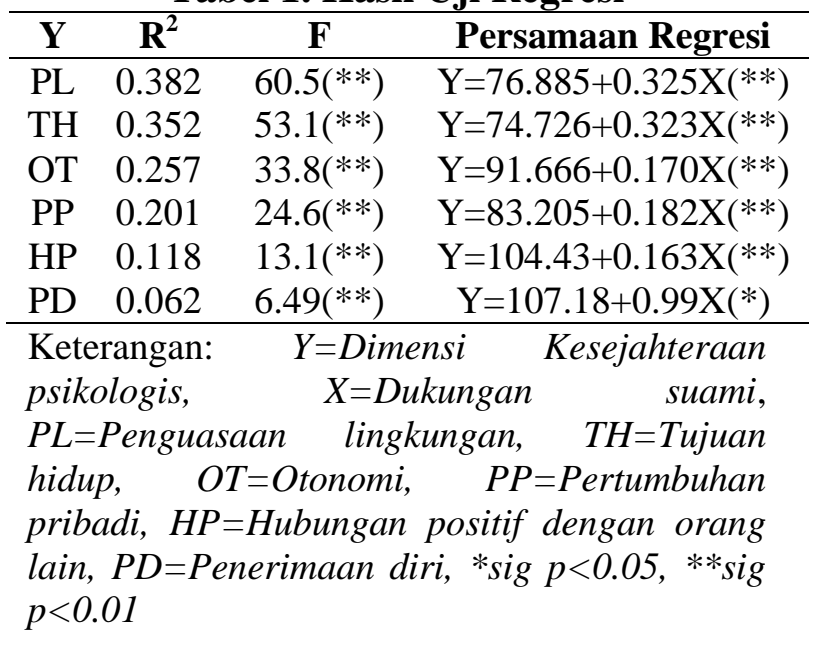

Berdasarkan tabel 1, ditemukan bahwa terdapat peran dukungan suami yang signifikan terhadap penguasaan lingkungan pada jurnalis perempuan $(\mathrm{F}=60.586, \mathrm{p}$ <0.01). Didapatkan juga koefisien determinasi $\mathrm{R}^{2}=0.382$, yang artinya besar peran dukungan suami terhadap dimensi penguasaan lingkungan adalah $38.2 \%$ dan $61.8 \%$ dipengaruhi oleh faktor lain. Selain itu, dari hasil persamaan regresi, ditemukan bahwa penambahan 1 angka pada dukungan suami akan diikuti pula penambahan angka sebesar $\mathrm{B}=0.325(\mathrm{p}<0.01)$ pada penguasaan lingkungan.

Selanjutnya, dukungan suami juga berperan signifikan terhadap tujuan hidup pada jurnalis perempuan $(\mathrm{F}=53.134, \mathrm{p}<$ $0.01)$. Koefisien determinasi $\mathrm{R}^{2}=0.352$, yang artinya besar peran dukungan suami terhadap dimensi tujuan hidup adalah $35.2 \%$ dan $64.8 \%$ dipengaruhi oleh faktor lain. Persamaan regresi menunjukkan bahwa pengaruh yang dihasilkan dari dukungan suami terhadap tujuan hidup adalah positif, yang artinya penambahan 1 skor pada dukungan suami akan diikuti dengan bertambahnya skor sebesar $\mathrm{B}=0.323$ $(\mathrm{p}<0.01)$ pada tujuan hidup jurnalis perempuan.

Pada dimensi otonomi, ditemukan bahwa terdapat peran dukungan suami secara signifikan terhadap otonomi pada jurnalis perempuan $(\mathrm{F}=33.858, \mathrm{p}<0.01)$. Di samping itu didapatkan juga koefisien determinasi $\mathrm{R}^{2}=0.257$, yang artinya besar dukungan suami terhadap dimensi otonomi adalah $25.7 \%$ dan $74.3 \%$ dipengaruhi oleh faktor lain. Selain itu dari hasil uji persamaan regresi ditemukan bahwa penambahan 1 skor pada dukungan suami juga akan diikuti dengan penambahan skor $\mathrm{B}=0.170 \quad(\mathrm{p}<0.01)$ pada otonomi jurnalis perempuan.

Temuan lainnya adalah terdapat peran signifikan dari dukungan suami terhadap pertumbuhan pribadi pada jurnalis perempuan $(\mathrm{F}=24.683, \mathrm{p}<0.01)$. Koefisien determinasi $\mathrm{R}^{2}=0.201$, yang artinya besar peran dukungan suami terhadap dimensi pertumbuhan pribadi adalah sebesar 20.1\%, dan $79.9 \%$ dipengaruhi oleh faktor lain. Peran yang dihasilkan berada pada arah positif, yang artinya bahwa penambahan 1 skor dari dukungan suami akan diikuti dengan semakin tingginya pertumbuhan pribadi jurnalis perempuan $(B=0.182, \mathrm{p}<0.01)$.

Pada dimensi hubungan positif dengan orang lain ditemukan bahwa terdapat peran dukungan suami yang signifikan $(F=13.082, p<0.01)$. Selain itu, didapatkan juga koefisien determinasi $\mathrm{R}^{2}=0.118$ yang artinya besar peran dukungan suami terhadap dimensi hubungan positif dengan orang lain adalah $11.8 \%$, dengan $88.2 \%$ dipengaruhi oleh faktor lain. Peran yang dihasilkan bersifat positif, sehingga penambahan 1 skor pada dukungan suami akan berperan terhadap penambahan skor sebesar $B=0.163(p<0.01)$ pada hubungan positif dengan orang lain. 
Selanjutnya pada dimensi penerimaan diri, terdapat juga peran positif yang signifikan dari dukungan suami bagi penerimaan diri pada jurnalis perempuan $(\mathrm{F}$ $=6.490, \mathrm{p}<0.05)$. Selain itu didapatkan koefisien determinasi $\mathrm{R}^{2}=0.062$, yang artinya besar peran dukungan suami terhadap dimensi penerimaan diri adalah $6.2 \%$ dan $93.8 \%$ dipengaruhi oleh faktor lain. Peran positif yang dihasilkan mengindikasikan bahwa semakin bertambahnya 1 skor dukungan suami, maka bertambah pula skor penerimaan diri yang dimiliki jurnalis perempuan sebesar $\mathrm{B}=0.99(\mathrm{p}<0.01)$.

Dengan demikian, berdasarkan hasil analisis statistik ditemukan bahwa dukungan suami berperan signifikan terhadap kesejahteraan psikologis jurnalis perempuan pada setiap dimensi, khususnya pada dimensi penguasaan lingkungan dan tujuan hidup.

\section{DISKUSI}

Hasil dari penelitian ini adalah terdapat peran yang positif dan signifikan dari dukungan suami terhadap setiap dimensi kesejahteraan psikologis pada jurnalis perempuan. Dengan demikian, hipotesis penelitian diterima. Hasil penelitian ini sesuai dengan hasil penelitian yang dilakukan Tusya'ni (2007) yang menyatakan semakin tinggi dukungan suami maka semakin tinggi tingkat kesejahteraan psikologis. Jhonson dan Jhonson (1991) menyatakan bahwa dukungan sosial dapat meningkatkan kesejahteraan psikologis seseorang.

Berdasarkan hasil regresi, ditemukan bahwa dukungan suami berpengaruh positif paling besar terhadap penguasaan lingkungan pada jurnalis perempuan. Individu dengan penguasaan lingkungan yang tinggi memiliki kemampuan untuk menguasai dan mengendalikan diri dengan lingkungan sekitar, mengembangkan potensi dalam berbagai situasi dan kondisi, dan memiliki keterampilan dalam menggunakan kesempatan serta peluang yang muncul (Ryff \& Keyes dalam Wells,
2010). Bila dilihat dari hasil, maka terlihat bahwa dukungan suami mampu membuat para jurnalis perempuan dapat menguasai dan mengendalikan dirinya pada lingkungan, mengembangkan potensi yang telah dimilikinya, serta dapat mengolah pekerjaannya yakni bekerja sebagai jurnalis maupun pekerjaan domestik. Hal ini sejalan dengan hasil penelitian Sarason, et.al (1983), bahwa individu yang menerima dukungan sosial yang positif selama hidupnya cenderung memiliki keyakinan akan kemampuannya dalam mengendalikan berbagai situasi yang dihadapinya.

Pada dimensi tujuan hidup, dukungan suami juga berkontribusi positif dan signifikan. Individu dengan tujuan hidup yang tinggi akan merasa bahwa masa lalu dan masa sekarang yang sedang dijalaninya memiliki arti, serta memiliki keyakinan bahwa mereka memilki tujuan hidup dan memandang hidup merupakan bukan suatu hal yang sia-sia (Wells, 2010). Bila dilihat dari hasil, maka dapat dikatakan bahwa dukungan suami mampu membuat para jurnalis perempuan memiliki arti, serta memiliki keyakinan bahwa mereka memiliki tujuan hidup. Hal ini sejalan dengan hasil penelitian Sarason, et.al. (1983), bahwa individu yang menerima dukungan sosial yang positif selama hidupnya cenderung memandang segala sesuatu secara positif dan optimistik dalam kehidupannya.

Pada dimensi otonomi, dukungan suami juga ditemukan dapat memprediksi otonomi pada jurnalis perempuan secara positif. Individu dengan otonomi yang tinggi, dapat bersikap tegas dalam mengambil keputusan yang baik dan dapat mencoba untuk mengevalusi berbagai bentuk tekanan sosial (Ryff \& Keyes dalam Wells, 2010). Bila dilihat dari hasil, maka dapat dikatakan bahwa dukungan suami mampu membuat jurnalis perempuan bersikap tegas dalam hidupnya, mengambil keputusan yang baik, dan dapat mencoba untuk mengevaluasi berbagai bentuk tekanan sosial. 
Pada dimensi pertumbuhan pribadi, dukungan sosial dari suami juga berkontribusi positif pada jurnalis perempuan. Individu dengan pertumbuhan pribadi yang tinggi merasa ingin terus berkembang, terbuka pada hal baru, dan mampu menemukan cara untuk menuju perubahan yang dapat mengembangkan potensi (Ryff \& Keyes dalam Wells, 2010). Oleh karena itu, pada jurnalis perempuan yang mendapatkan dukungan suami yang tinggi akan membantunya untuk terbuka untuk hal yang baru, merasa ingin terus berkembang serta mengembangkan potensi yang dimiliki.

Kontribusi dukungan suami terhadap hubungan positif dengan orang lain ditemukan signifikan dan menunjukkan arah yang positif, namun lebih rendah dibandingkan kontribusinya pada dimensi lainnya. Terdapat faktor lain yang lebih mempengaruhi hubungan positif pada jurnalis perempuan. Individu yang memiliki nilai yang tinggi pada dimensi ini memiliki perhatian terhadap kesejahteraan orang lain, mampu berempati, menyayangi, menjalin keintiman (intimacy) dengan orang lain, memahami konsep memberi dan menerima dalam membina hubungan dekat dan saling percaya dengan orang lain (Lakoy, 2009). Pada jurnalis perempuan meskipun dukungan suami dapat membantu meningkatkan kemampuan empati, mempunyai kepercayaan, dan mampu berhubungan dengan orang lain dengan baik, namun terdapat faktor lain yang lebih mempengaruhi dibandingkan dukungan suami positif dengan orang lain. Faktorfaktor ini perlu diteliti lebih lanjut dalam penelitian selanjutnya.

Dukungan suami juga memiliki kontribusi yang signifikan dan positif, namun paling rendah pada dimensi penerimaan diri. Individu yang dinilai rendah pada dimensi ini merasa tidak puas terhadap dirinya, selalu melihat kekurangan yang ada pada dirinya, dan melihat hal tersebut merupakan sesuatu yang tidak dapat diperbaiki (Ryff dalam Wells, 2010). Pada jurnalis perempuan, dukungan suami dapat membantu mengatasi kekurangan yang dimilikinya, namun kontribusinya tidak besar dan terdapat faktor-faktor lain yang lebih mempengaruhi yakni sebesar $93,8 \%$. Adapun faktor lain yang bisa mempengaruhi misalnya pengakuan akan keterbatasan diri (Chaplin dalam Mashithah, 2012).

Gambaran penguasaan lingkungan yang tinggi pada jurnalis perempuan dapat juga dikaitkan dengan karakteristik dari pekerjaan para jurnalis itu sendiri. Jurnalis perempuan yang dapat bertahan dalam pekerjaan hanyalah mereka yang dapat survive pada pekerjaan. Sulaeman (2014) juga menyatakan bahwa seorang jurnalis adalah sosok yang harus perlu mempersiapkan diri dan belajar sebaikbaiknya agar dapat membaca situasi dimana mereka berada dan bekerja.

Terkait tujuan hidup yang tinggi, Yuniati (2012) mengungkapkan beberapa tujuan perempuan bekerja sebagai jurnalis adalah ingin mewujudkan mimpi-mimpi kaum perempuan untuk memperkuat eksistensi diri dalam berbagai sektor, salah satunya di bidang jurnalistik. Oleh karena itu, sebagian besar dari jurnalis perempuan ini memiliki tujuan hidup yang tinggi.

Ditemukan pula bahwa dimensi hubungan positif dengan orang lain cenderung lebih rendah dibandingkan dengan dimensi yang lainnya pada jurnalis perempuan. Gambaran ini mengindikasikan bahwa jurnalis perempuan cenderung kurang bisa berhubungan dengan orang lain, karena pekerjaan para jurnalis cenderung lebih banyak dilakukan secara individual. Yuniati (2012) mengungkapkan bahwa pekerjaan di bidang jurnalistik cenderung lebih individual. Banyaknya tuntutan dalam pekerjaan dan banyaknya deadline membuat para jurnalis sulit bersosialisasi dengan yang lainnya.

\section{SIMPULAN}

Hasil penelitian menunjukan bahwa dukungan suami berperan positif dan signifikan bagi kesejahteraan psikologis pada jurnalis perempuan. Ditemukan bahwa 
semakin besar dukungan suami yang diterima, maka berkontribusi pada kesejahteraan psikologis yang lebih tinggi. Dengan dukungan suami yang tinggi, jurnalis perempuan akan merasa lebih mampu menerima dirinya, mempunyai tujuan hidup, memiliki keterampilan untuk mengambil kesempatan yang muncul, mempunyai keinginan untuk mengembangkan potensi, dan dapat membangun hubungan positif dengan orang lain.

\section{SARAN}

Secara metodologis, mengingat bahwa dukungan sosial dari suami tidak berkontribusi besar pada dimensi hubungan positif dengan orang lain, pertumbuhan diri, dan penerimaaan diri, maka pada penelitian selanjutnya agar dapat meneliti faktorfaktor lainnya yang memiliki kontribusi lebih besar terhadap dimensi-dimensi ini.

Hasil penelitian ini mengindikasikan bahwa usaha meningkatkan kesejahteraan psikologis perempuan yang bekerja, khususnya sebagai jurnalis perlu dimulai dari penerimaan dan penghargaan dari suami. Oleh karena itu, bagi suami dari perempuan yang bekerja, hendaknya memberikan dukungan berupa perhatian, pengertian, ekspresi, serta nasihat-nasihat sehingga dapat meningkatkan kesejahteraan psikologis sang istri.

\section{DAFTAR PUSTAKA}

Azwar, S. (2012). Penyusunan skala psikologi. Yogyakarta: Pustaka Pelajar.

Badan Pusat Statistik (BPS). (2008). Analisis perkembangan statistik ketenagakerjaan (Laporan Sosial Indonesia 2007). Jakarta.

Baron, A.R. \& Byrne,D. (2005). Psikologi sosial jilid 2. edisi 10. Jakarta: Airlangga.

Brebahama, A., \& Listyandini, R. A. (2016). Gambaran tingkat kesejahteraan psikologis penyandang tunanetra dewasa muda. Mediapsi, 2(1), 1-10.

Dennis, F. (2008). Bekerja sebagai wartawan. Jakarta. PT.Gelora Aksara Pratama.

Deny, S. (2014). 42\% wanita RI lebih pilih bekerja dari pada diam di rumah. Diakses dari www.liputan6.com pada tanggal 9 Oktober 2015.

Febriarni, U. (2012). Motivasi kerja perempuan jurnalis: Identifikasi dan implikasi organisasional. Skripsi. Universitas Islam Indonesia. Yogyakarta.

Gottlieb, B. H., \& Bergen, A. E. (2010). Social support concepts and measures. Journal of psychosomatic research, 69(5), 511-520.

Johnson, W. \& Johnson F.P. (1991). Joining together. Prentice-Hall. Inc: USA.

Krause, N., \& Ellison, C. G. (2003). Forgiveness by God, forgiveness of others, and psychological well-being in late life. Journal for the scientific study of religion, 42(1), 77-93.

Lampe, I. (2010). Perempuan dalam Pengelolaan Surat Kabar di Sulawesi Tengah (Studi Posisi dan Peran Perempuan dalam Media Cetak). Academica, 2(1).

Lahagu, A. D. (2012). Problem perempuan jurnalis dalam praktik jurnalisme berperspektif gender (Studi Kualitatif Tentang Pengalaman Subjektif Perempuan Jurnalis dalam Praktik Membangun Jurnalisme Berperspektif Gender di Surat Kabar Kedaulatan Rakyat). Doctoral dissertation. Universitas Atmajaya Yogyakarta.

Nieva, V. F., \& Gutek, B. A. (1981). Women and work. New York: Preager Nurmadina, M. (2008). Hubungan antara dukungan suami dengan kecemasan pada wanita menopause. Skripsi. Universitas Sumatera Utara.

Portal Resmi Provinsi DKI Jakarta. (2014). Keadaan Ketenagakerjaan di DKI Jakarta Februari 2014. 
Ryff, C. D. (1989). Happiness is everything, or is it? Explorations on the meaning of psychological wellbeing. Journal of personality and social psychology, 57(6), 1069.

Ryff, C. D., \& Singer, B. (1996). Psychological well-being: Meaning, measurement, and implications for psychotherapy research.

Psychotherapy and psychosomatics, 65(1), 14-23.

Sarafino, E.P. (2011). Health Psychology: Biopsychososial Interaction. Seventh Edition. New York: John Wiley and Sons, Inc.

Sarason, I. G., Levine, H. M., Basham, R. B., \& Sarason, B. R. (1983). Assessing social support: The social support questionnaire. Journal of personality and social psychology, 44(1), 127.

Sulaeman, H. (2016). Studi profesionalisme melalui pengalaman komunikasi jurnalis perempuan di media massa kota ambon. Fikratuna, 7(2).

Tusya'ni, A. (2007). Hubungan dukungan sosial dan kesejahteraan psikologis pada ibu bekerja di kantor sekretariat daerah Pemerintahan Provinsi Jawa Tengah. Undergraduate Thesis. Universitas Diponegoro.

Wells, I.E. (2010). Psychological Wellbeing. New York: Nova Science Publishers, Inc.

Yuniati, Y. (2012). Citra jurnalis perempuan. Diunduh ari http://www.academia.edu/4921914/Y enni_Yuniati_CITRA_JURNALIS_I NDONESIA pada 1 Maret 2016. 